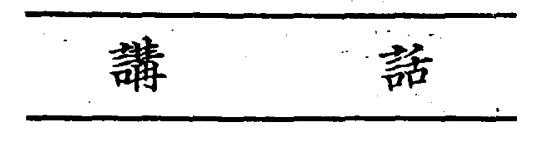

統 訫 方 法 概 說

近藤 忠 篗

\title{
第2章「カイ」自乘試驗
}

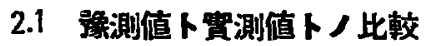

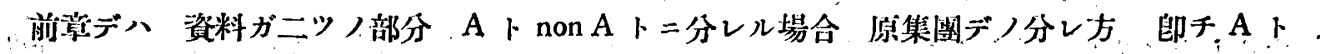

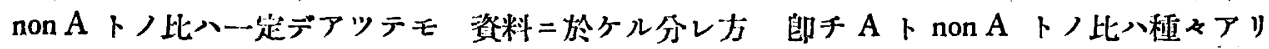
コノ比ニヨツテ多數ノ資料

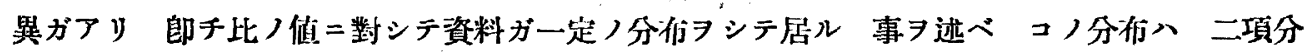

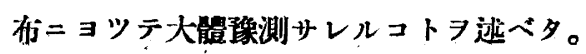

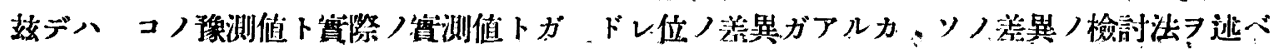
ヨウ。

侧へバ 1.1 表二於ケル5 兒管庭ノ分们ノ實测值习性比 $1: 1$ ナルトキノ豫测值卜比較シテ 2.1 表二示ス樣ナ检討 7 行ツテ見ル。

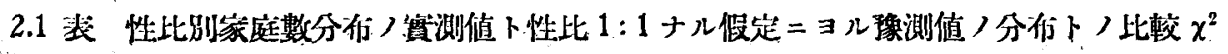

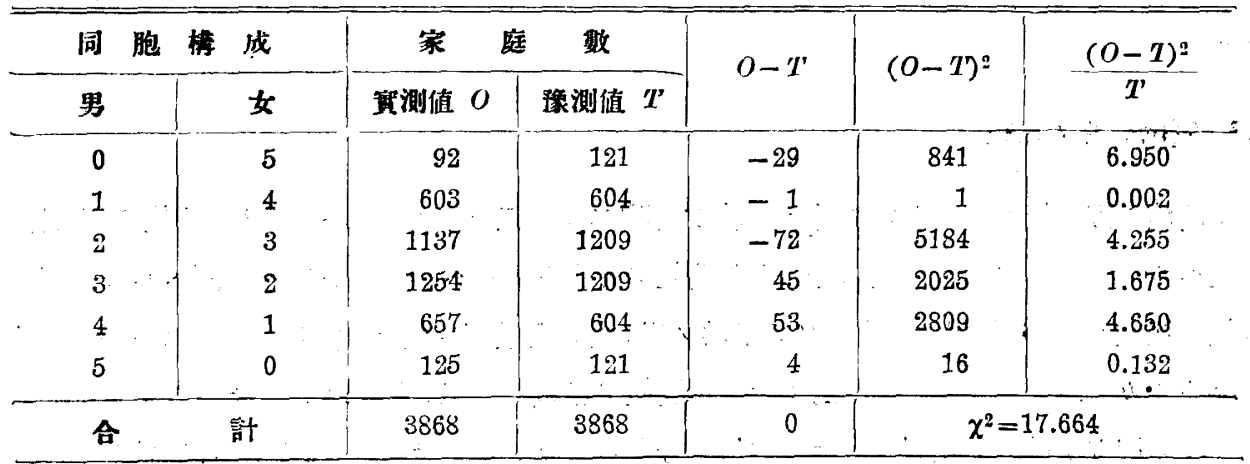

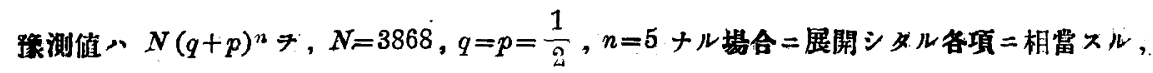

此ノ栐ナ計算、Barlow"，表，計算尺，算盤等タ使へバ甚ダ简單二出来ル。

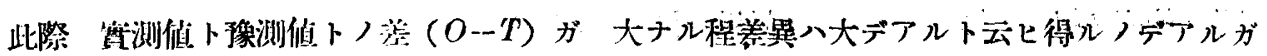
$\left(O-T^{\prime}\right)>6$ 㑬)值 7 全部合竍スレバ 


$$
\sum(O-T)=0
$$

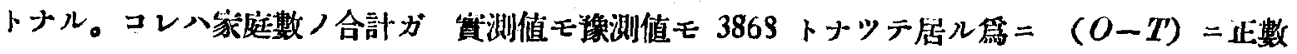
ト負數トガア!互二相殺スルカラデアル。

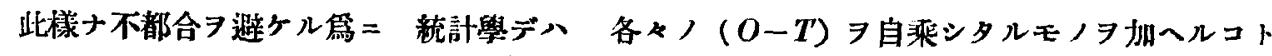
トシティル。郎チ

$$
\sum(O-I)^{2}
$$

デアル。

然シ合妶ニ考へナケレバナラヌ事ハ例へバ

$O=10 \quad T=8 \quad$ ナルトキト

$O=20 \quad T=18 \quad$ ナルトキトデハ共=

O-T=2 デアルガ ソノ $(O-T)$ ノ示ス實祭的意義、 $T=8$ ケルトキノ方カ $T=18$

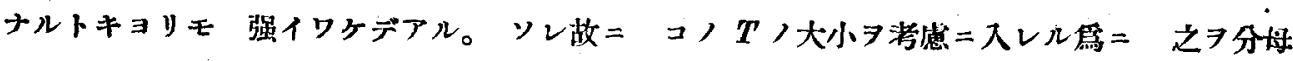
トシテ

$$
\sum \frac{\left(O-I^{\prime}\right)^{2}}{T}
$$

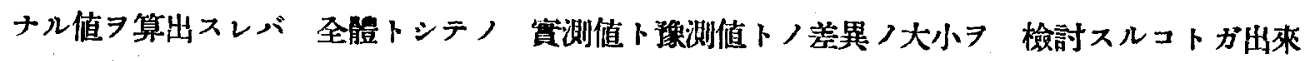
ル。コノ栐ニシテ算出シタ值 7 「イ」自乘 $\left(\chi^{2}\right.$, chi-square $)$ ト云フ。

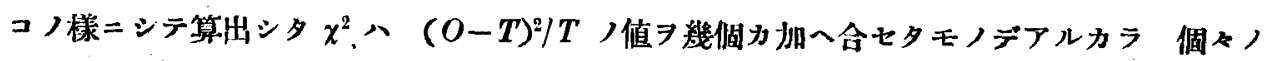

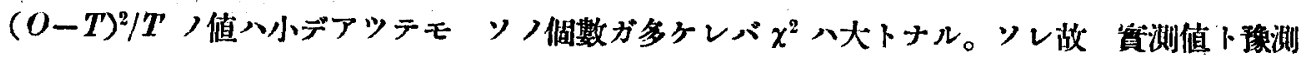
值トノ大小シ憸討スル二八 $\chi^{2}$ ノ大小ト同時 $=$ ソレガ幾個ノ $(O-T)^{2} / T$ /值ノ和デアル カラ 常ニ考へニスレナケレバナラナイ。此ノ事八後二自由度数ナル概念フ非ベル時二說明 スル。

\section{2 筑的分布ノ比較}

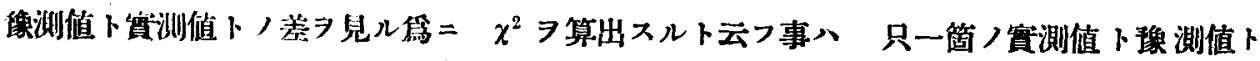

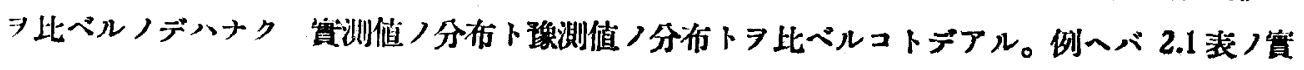
测值ノ級數入 3868 個ノ家庭ガソノ子供ノ男:女ノ人數别二就テ 如何=分配 (distribute)サ レテキルカシ示シティル。え゙對シテ 豫測值ノ級數入 男:女=1:1=ナルトキ=5 兒家 遮 3868 個ガ于供ノ性此别二就テ 如何二分布スルカラ示シテ居ル。2.1表=示ス樣= $\chi^{2}$ ， 倠习算出スルト云フコトハコノ网㨋ノ分布 (Distribution) ガ.如何二互二異ツテ居ルカト云 フ 程度ノ目安ヨ算出スルコトデアル。モシ此ノ $\chi^{2}$ ガ或限界值以上デアレン゙ 兩者ノ分师入 誤美つ範圍习超エテ異ツテッルト見做シ得ルノデアル。

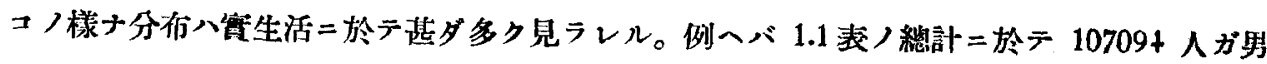


55043 人卜女 52051 人ト =分レテ居ル, 之モーツノ分布デアル。此ノ場合/級/數 (Number

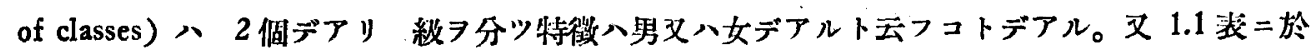
テ28713 個ノ笔庭ガ 1 兒家庭 3368,2 兒家庭 $5143 \cdots \cdots \cdots$, ト云フ風二分布シテ居ル。此ノ際 ノ級ノ數八 10 デアリ級ノ特徴八同胞數デアル。又先=述ベタ 5 兒家庭 3868 個ノ分布ガ示 ス 2.1 裴ノ如キ級ノ特徴入性比デアル。

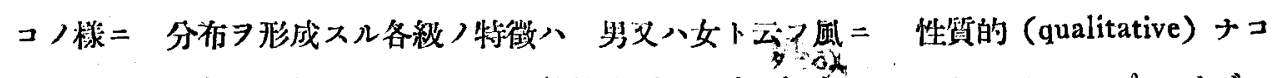
トモアリ，同胞數トカ性比トカ云フ風二数量的（qnantitatie)

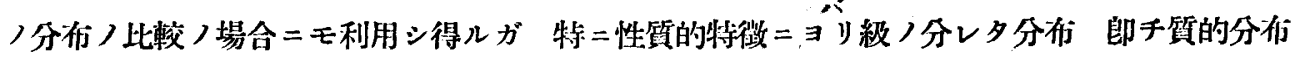
(qualitative distribution) /時ニ八 是非必要デアル。文数量的ナ特徽ニヨル分仍 即千量的 分布 (quantitative distribution) =於テモ 各級ノ示ス數量的特徽ガ等間隔デナイ場合ニモ亦 $\chi^{2}$ ハ便利デアル。

\section{$2.3 \chi^{2}$ 八分布}

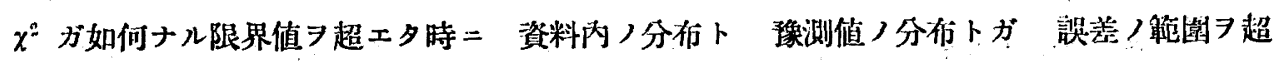
エテ 相異ツテ居ル ト云ヒ得ルダラウカ。コノ限界值八 既二算出サレテ装ニナツテ居ルガ

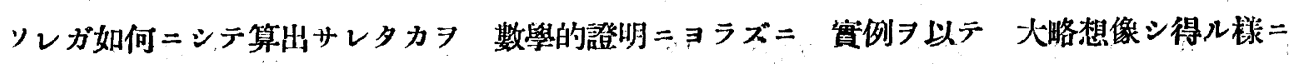
說明シテ見ヨウ。

先ヅ一番簡單ナ場合トシテ 分布つ級ノ数ガ 2 個ナル時ヨ考ヘテ見ル。ココー無限大ノ人數 ヨリ成ル原集禺ガアツテソノ人數ノ $\frac{1}{2}$ ハ男デアリ他ノ $\frac{1}{2}$ ハ女デアルトスル。此ノ場合 級 ノ特徽八男义ハ女デアル。此ノ原集国カラ 5 人 1 組ノ資料习㭴山作ツテ見ル。ソノ時 各資

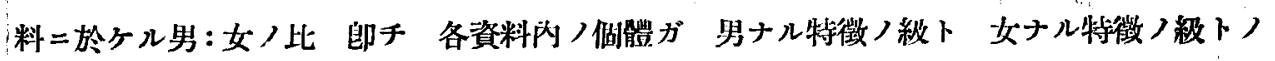
二ツノ級=分布スル有様八 2.1 表二示ス樣= $0: 5,1: 4,2: 3,3: 2,4: 1,5: 0$ 人 秝デ アル。コノ5人 1 組ノ資料习谌ダ多ク $N$ 組作ツテ・ソ $N$ 組カ 性比别=如何=分布スル カ ヨ像想スレバ モシ資料ノ作リ方ガ正シヶレバ 即チ 資料

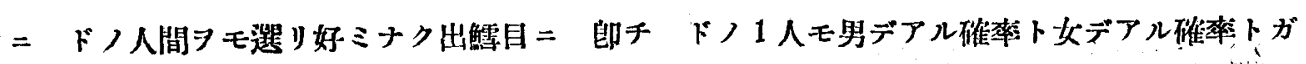

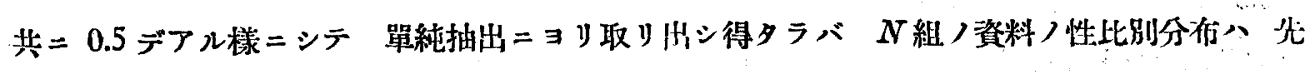
二迹ベタ二項分布 即チ

$$
N(0.5+0.5)^{5}
$$

ナル式ノ展開ノ各項二相當スル管デアル。例ヘバ $N=3868$ ナル時八 2.1 装ノ豫洲值ノ行 ニ示シタ 6 個つ数值トナル。

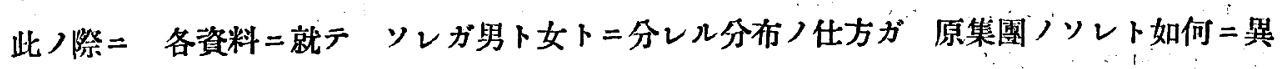
ルカヨ示ス $x^{2} \Rightarrow$ 算出シテ見ルト 2.2 表ノ如クナル。之ヨ見ルト 同一原集團カラ 取り 出シタ資料デモ 原集團内ノ分价ト著シク異ル分布ヨ示シテ $\chi^{2}$ ガ 5.0 ト云フ様ニ大トナ゙ルモ 
2.2 践 闹胞 5 人ガ男: 女二分布ス儿場合，男:女 $=1: 1$

ナル場合トノ渼異习亦す $\chi^{2}$

\begin{tabular}{|c|c|c|c|c|c|c|c|c|c|c|}
\hline \multirow{2}{*}{ 統 } & \multicolumn{2}{|l|}{ 性 } & 比 & \multirow{2}{*}{$\chi^{2}$} & \multicolumn{2}{|r|}{ 家 } & \multicolumn{2}{|c|}{ 庭 } & \\
\hline & 唁 & 值 & 效 & & 㮱 & 澌 & 值 & 同 & 比 & 卒 \\
\hline & $0: 5$ & & $2.5: 2.5$ & 5.0 & & 121 & & & 0.03125 & \\
\hline & $1: 4$ & & $2.5: 8.5$ & 1.8 & & 604 & & & 0.15625 & \\
\hline & $:: 3$ & & $2.5: 25$ & 0.2 & & 1209 & & & 0.31250 & \\
\hline & $3:$ บ & & $2.5: 2 \mathrm{~s}$ & 0.9 & & 1209 & & & 0.31250 & \\
\hline & $4: 1$ & & $2.5: 2.5$ & 1.8 & & 604 & & & 0.15625 & \\
\hline & $5: 0$ & & $2 . \overline{5}: 2 . \overline{5}$ & 5.0 & & 121 & & & 0.03125 & \\
\hline & & & & & & 3868 & & & 1.0000 & \\
\hline
\end{tabular}

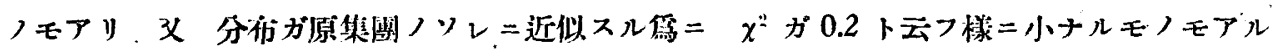

1. 云つ事分分几。

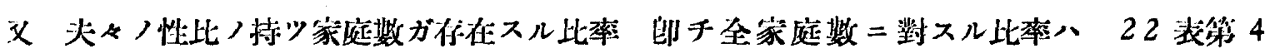

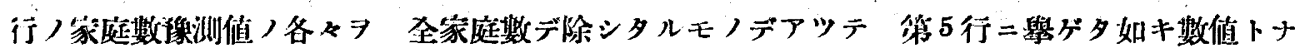

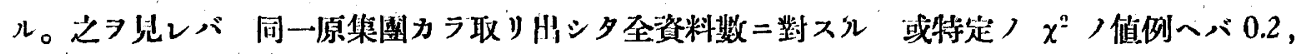

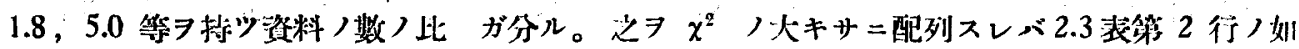

2,3 装 同一原集畴二閩 几資料ノ示ス $\chi^{2}$ ノ種くナ 几值ノ起儿比率

\begin{tabular}{c|c|c}
\hline$\chi^{2}$ & Y, 比粟 & 比率暴䅆 \\
\hline 5.0 & 0.0625 & 0.0625 \\
1.8 & $0.31 \pm 5$ & 0.3750 \\
0.2 & 0.6250 & 1.0000 \\
\hline
\end{tabular}

クナル。

2.3 表ノ如ク同一原集團》 ラ取リ出サレタ各資料二就テ $\chi^{2}$ ヨ算出シタ值が 幾何ナル 埸合、全體ノ場合二對シテ
2.1 温 $\chi^{2}$ 八比臬ノ分们 $\nu=1$ /場合 (Snedecor $\exists$ i)

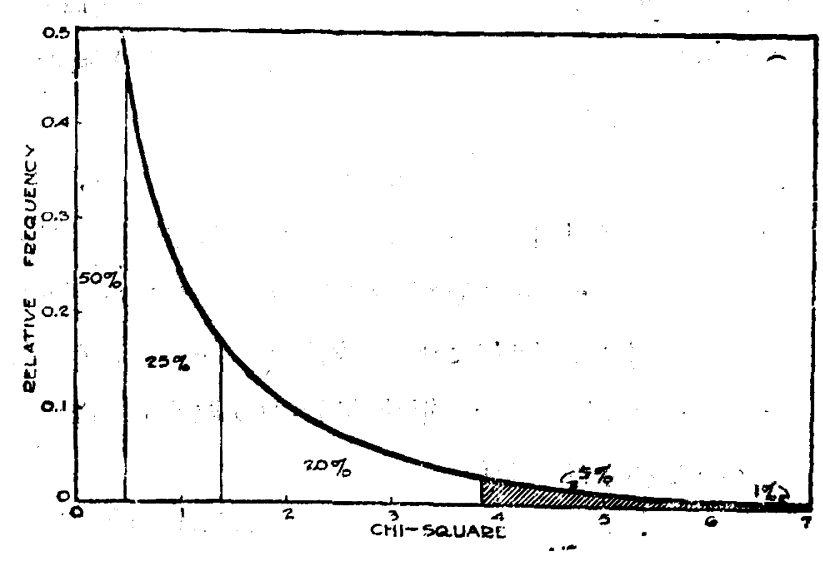

幾们ノ比率习以テ存在スルカヨ示スモノ $\chi^{2}$ ノ分布 (Distribution of $\chi^{2}$ ) ト云フ。モ

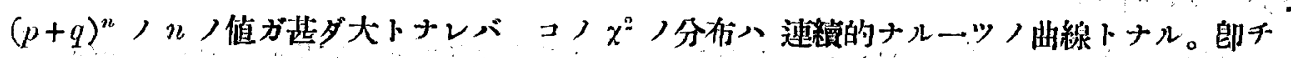
2.1 [㔊)如キモノデアル。 


\section{$2.4 x^{2} /$ 保萃}

2.4 表=於ヶル第 3 行ノ比來ノ照積ナルモノ八 如何ナル事ヨ表ハシテ居ルカト云へバ 之

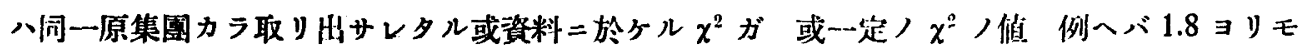
大デアル碓率八 幾何デアルカ ヨ示シテ居ル。郎チ 2.3 表二就テ云へバ $\chi^{2}$ ガ 1.8 以上デ

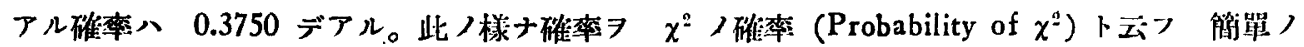

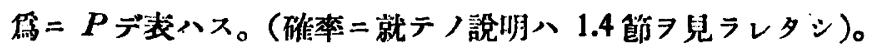

コノ $\boldsymbol{P}$ 八 $\chi^{2}$ ノ值ガ大トナル程 小トナル。何トナレバ 同一原集國カラ取り出サレタ資

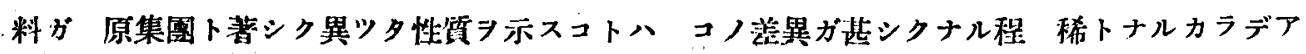

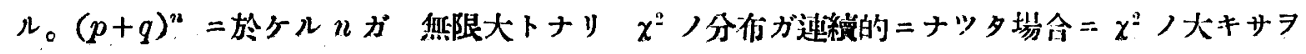

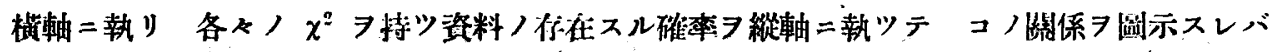
2.1 滰ノ如クナル。

2.1 圆ノ如キ場合に $\chi^{2}$ ノ火キサト， $\chi^{2}$ ガソレ以上ニ大トナル碓率 即チ $\chi^{2}$ ノ碓率卜ヨ装 示スレバ 2.4 第2 行ノ如タナル。

2.4 表 $\chi^{2}$ 八碓率 $P, \nu=$ 自由 度数 $(\nu=2$ ナル場命二就テ 八第 3 亲二述べル)

\begin{tabular}{cc|c|c}
\hline$P$ & $\nu$ & 1 & 2 \\
\hline .99 & & .00016 & .0201 \\
.95 & .0039 & .103 \\
.50 & .455 & 1.386 \\
.30 & 1.074 & 2.408 \\
.20 & 1.642 & 3.219 \\
.10 & 2.706 & 4.605 \\
.05 & 3.841 & 5.991 \\
.01 & 6.635 & 9.210 \\
\hline
\end{tabular}

即チ原集国ガ二ツ/級ニ分レル㥞ナ場合ニツレ

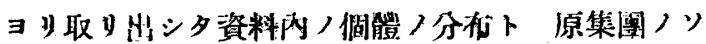
レニ等シイ場合/分有トヨ比ベテ見ルトツノ $\chi^{2}$ ガ 例へバ 3.841 ヨリ火ナル場合”、全資料， 中） 0.05 即千 $5 \%$ =於テ起儿事が 確カラシイ

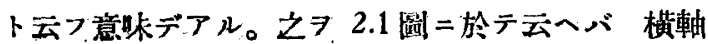
$=3.841$ ナル做 7 執り ソレョリ立テタ垂線ノ右側 ニアル曲線下ノ面積 郎手圖二於:科線付ヶノ部分 ノ面棹八曲線下ノ全面稪ノ $5 \%=$ 相當スルト云フ 事デアル。

撸言スレパ $\chi^{2}$ ノ碓率ト云フモノハ ソノ資料

邓’個體ノ分俳ガアル特定ノ分优ト一致スルト云ヒ得ル確率 ヨ示スモノデアル。ソレ故

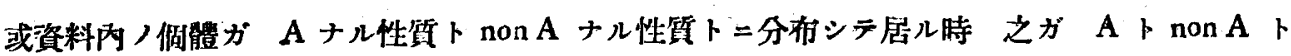
ガ或特定ノ割合ニナツテ居ル所ノ分㛂 ト一玫シテ居ルト見做シテ良イカ否カハコ/特定ノ

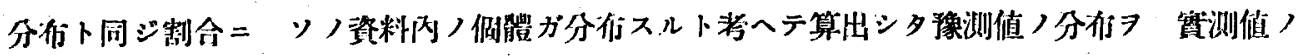

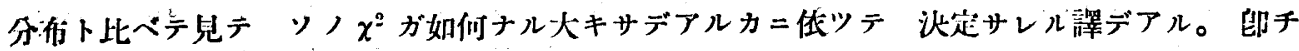

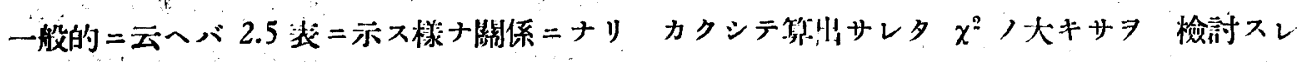
パ良イノデアル。 
2.5 装 資料內ノ侗體ガ A ト non A ト =分レル際ノ $\chi^{2}$ ／算出法

\begin{tabular}{|c|c|c|c|}
\hline 储體，性貿 & $\mathbf{A}$ & $\operatorname{non} A$ & 計 \\
\hline 算 测 值 & $f_{\mathbf{A}}$ & fnon $\mathrm{A}$ & $N$ \\
\hline 理 测 值 & $f_{\mathrm{A}}$ & $f^{\prime}{ }_{\text {non A }}$ & $N$ \\
\hline
\end{tabular}

\section{$2.5 \chi^{2}$ 試駼}

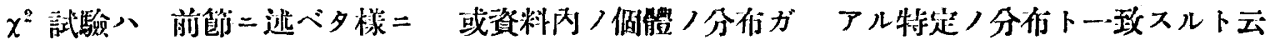
七得ル碓率 算出シテソノ大小ヨ檢討スルコトデアルガ コノ確率ガ幾何以下トナレバ コノ實测分布八特定，分布ト一致シテ居ナイ ト見做シテ差支へナイダラウカ。 理論的ニ宩へレバコノ $\chi^{2}$ ノ碓率八如何ニ小トナツテモ ソノ碓率二相常スルダケハ ソ

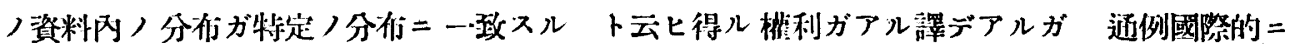

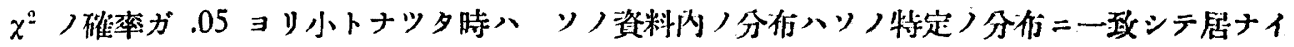
ト見做シテ若支へナイコトニシテ居ル。

$\chi^{2}$ ノノ確率ガ .05 ヨリ小ナル時二、 之 $7 \chi^{2}$ ガ有意 (significant) デアルト云フ。 $P<.01$ ナル時八著シク有意 (highly significant) ト云フノデアル。

モシ $P>.05$ 即チ $\chi^{2}$ ) 值ガ充分二大デナイ時二八 $\chi^{2}$ 八侍意デハナイ (non significant) 卜云フガ 之八ソノ資料內/分布ガソノ特定ノ分优二一致シテ居ナイトハ云へナイト云フ 意味デアツテ 一致シテ居ルト云へル ト云フ事ト、必ズシモ同一デハナイ。例へバ茹二 100 人ノ人ガ男:女 $=55: 45$ 二分レテ居タトスレバ ソレ八 $50: 50$ ナ儿特定ノ分布卜八有 意的二異ナツテ居ルト入云へナイ。何トナレバ $\chi^{2}=5 \% / 50+5 \% / 50=1$ デ $P>.05$ デアルカラ。 シカシモシ 500 人ノ人ガ同ジ制合 即チ男:女=275:225二分レテ居タトスレバ 之八 250 : 250 ナル分布卜入 $\chi^{2}=25^{2} / 250+25^{2} / 250=5 \quad$ デアリ $P<.05$ デアルカラ $\chi^{2}$ 八准意デアル カラ 有意的=異ツテ居ル ト云ヒ得ルノデアル。ソレ故同ジ性籍（例へバ男:女 $=55: 45=$ $275: 225$ ) ノ資料デモ ソノ大キサガ小ナル時八 $\chi^{2}$ 八有意トナラナイコトガアルカラ 上記

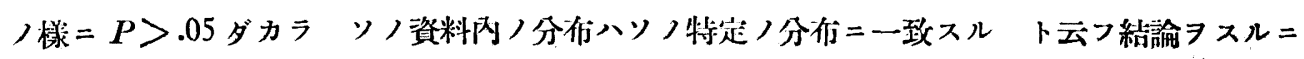
八壃重ナルコトヨ丽スールデアル。

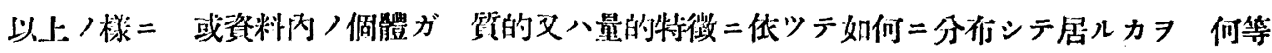

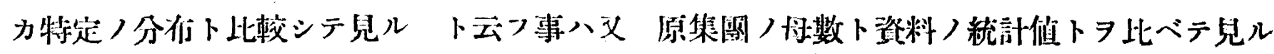

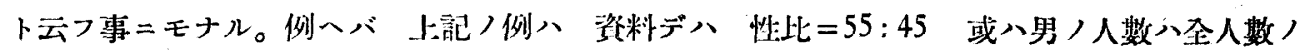

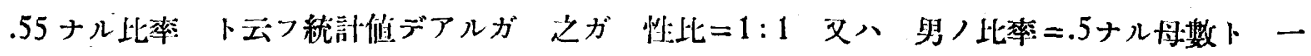

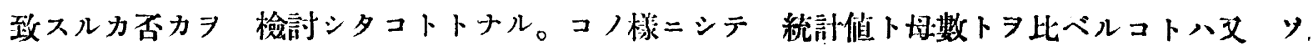




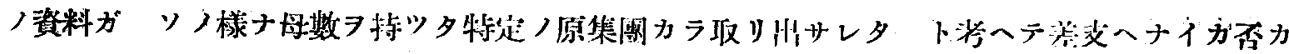
ヨ检討スルコトニモナルノデアル。

\section{6 自由度数}

2.1 䬦ノ㩐ナ場合 $=5$ 元家庭ノ總数 3868 總人数 19340 人=於デ 性比ガ $1: 1$ 卜住意的

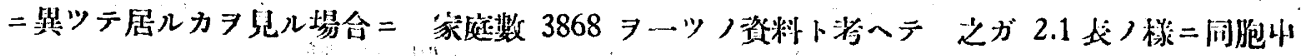

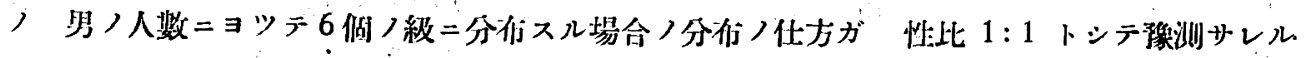

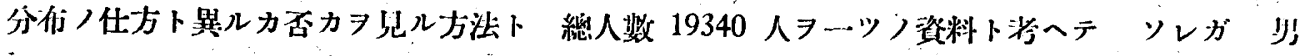

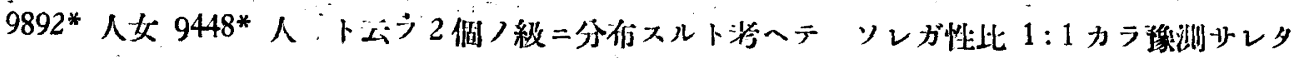

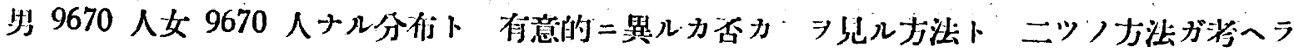
レル。前省ノ場合二八 2.1 表デ訃算シタ椾二 $\chi^{2}=17.664$ トナリ 後少ノ場介 $\chi^{2}=222^{2} / 9670+222^{2} / 9670=10.193 \quad$ ト+ $。$

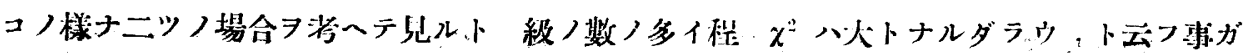

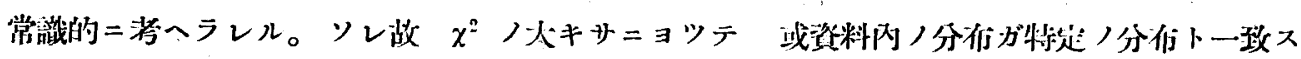

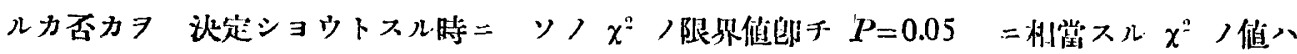

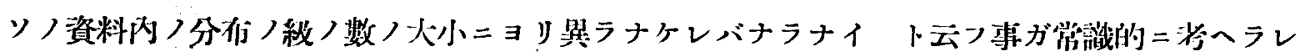
ル。

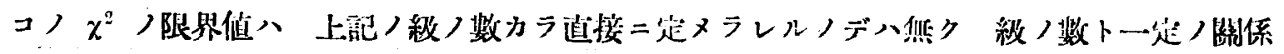
ヨ持ツ所ノ自由度数 (Number of degrees of freedom) =化ツデ 尖メラレルノデアル。

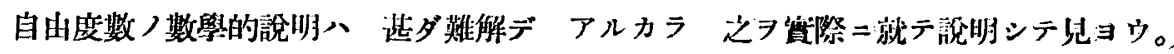

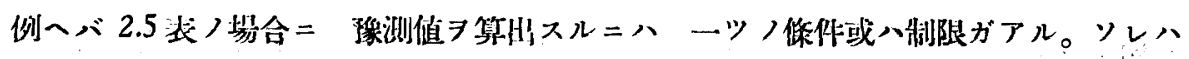

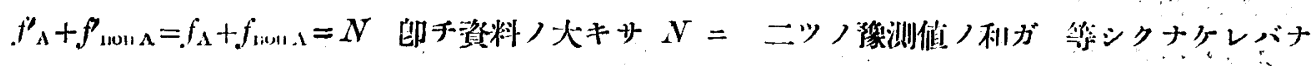

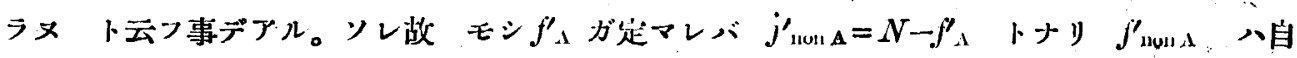

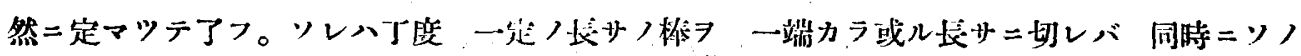

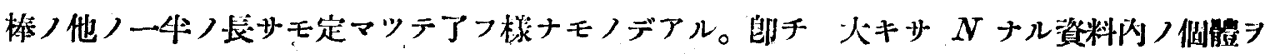

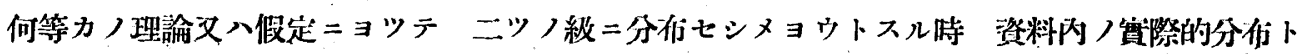

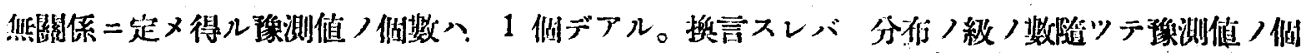

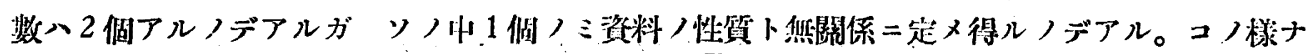

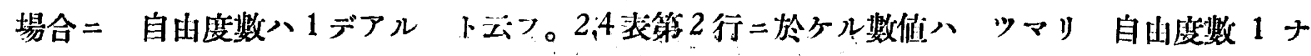
ル時ノ $\chi^{2}$ ノ確率デアル。

* 緗人数 $=5 \times 3868=19340$

男人數 $=92 \times 0+603 \times 1+1137 \times 2+1254 \times 3+657 \times 4+125 \times 5=989,2$

女人数 $=19340-9892=9448$ 


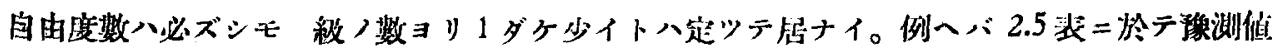

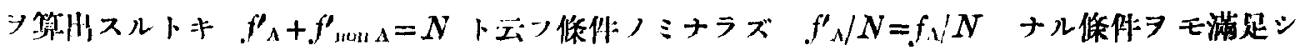

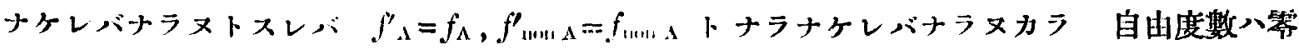
トナル。即チコノ場合二、自由度數八級ノ數ヨリ 2 ダケ少イ。

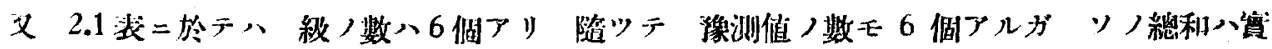

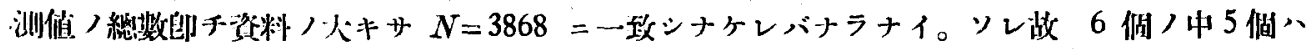

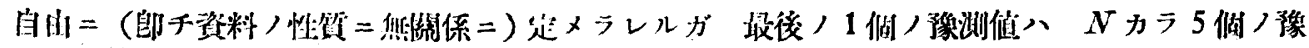
测值ノ和ヨ減ジタモノニ一玫シナケレバナラナイノデ 自山度數ハ5トナル。

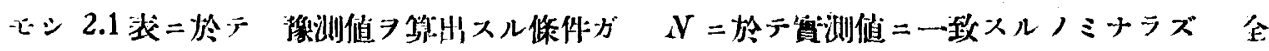

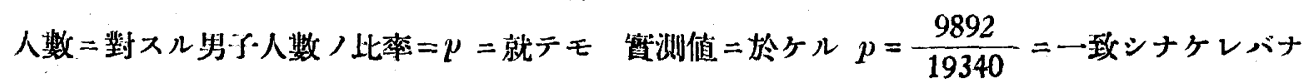
ラメトスレバ 自由度數、 5 デハナクテナトナル。何トナレバ 次ノ 2.6 表ノ如ク考へルト

2.6 装 男子人数别家庭数ノ實測值卜棵測檤

\begin{tabular}{|c|c|c|c|}
\hline 同胞中男子數 & 家庭敏惯測值 & 家庭数程測值 & 各種家庭男于總数 \\
\hline 0 & $f_{0}$ & $f_{\mathrm{n}}^{\prime}$ & $0 \times f_{0}^{\prime}$ \\
\hline 1 & $f_{1}$ & $f_{1}^{\prime}$ & $1 \times f_{2}^{\prime}$ \\
\hline$\ddot{J}$ & $f_{2}$ & $f_{2}^{\prime}$ & $2 \times f_{2}^{\prime}$ \\
\hline 3 & $f_{s}$ & $f_{s}^{\prime}$ & $3 \times f_{8}^{\prime}$ \\
\hline 4 & $f_{4}$ & $f_{4}^{\prime}$ & $4 \times f_{4}^{\prime}$ \\
\hline 5 & $f_{5}$ & $f_{5}^{\prime}$ & $5 \times f_{5}^{\prime}$ \\
\hline 計 & $N$ & $N$ & $5 N_{\mathrm{p}}$ \\
\hline
\end{tabular}

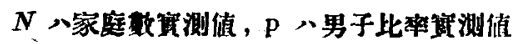

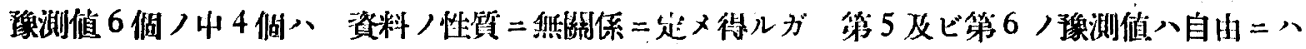

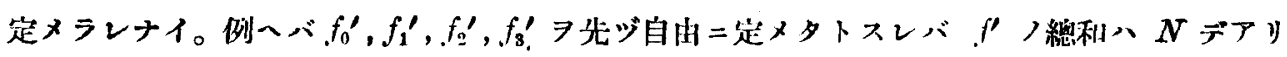
日 男ノ人數ノ總和、 $5 N_{p}$ デナケレバナラヌ ト云つ保件ノ下デ八

$$
\begin{gathered}
f_{1}{ }^{\prime}+f_{5}{ }^{\prime}=N-\left(f_{0}{ }^{\prime}+f_{1}{ }^{\prime}+f_{2}{ }^{\prime}+f_{3}{ }^{\prime}\right) \\
+\times f_{4}{ }^{\prime}+5 \times f_{5}{ }^{\prime}=5 N p-\left(0 \times f_{0}{ }^{\prime}+1 \times f_{1}{ }^{\prime}+2 \times f_{2}{ }^{\prime}+3 \times f_{3}{ }^{\prime}\right)
\end{gathered}
$$

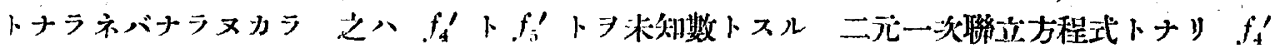

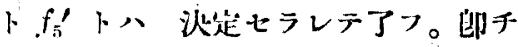

$$
\begin{gathered}
f_{4}^{\prime}=5 N(1-p)-\left(5 f_{0}{ }^{\prime}+4 f_{1}{ }^{\prime}+3 f^{2 \prime}+2 f_{3}{ }^{\prime}\right) \\
f_{5}{ }^{\prime}=N-\left(f_{0}{ }^{\prime}+f_{1}{ }^{\prime}+f_{2}{ }^{\prime}+f_{3}{ }^{\prime}+f_{4}{ }^{\prime}\right)
\end{gathered}
$$

トナル。故二此ノ場合二八 自由度數八級ノ數ヨリ2ダケ少イモノトナル。

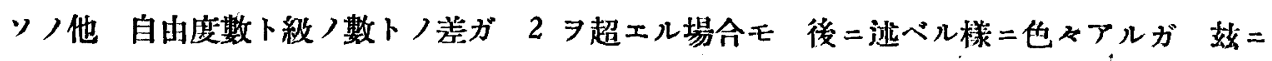

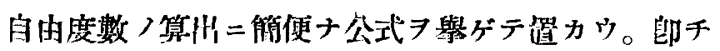




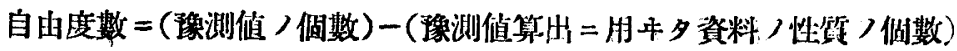

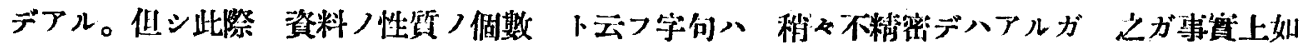

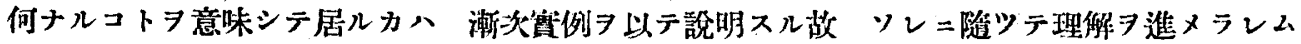
事习希毞スル。

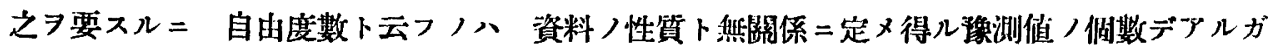

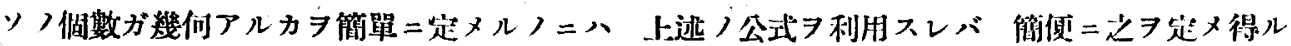
ノデアル。

\section{7 比率ノ母数ト統計值}

以上ノ考察力理解出來レバ 比率ノ母數郎千原集團ノ比率卜 比率ノ統計值郎于資料ノ比率 ト 比較檢討スルコトハ 甚ダ容易デアル。例へバ 或ル學校 $=$ 於テ 多年ノ經驗 $=$ ヨレバ

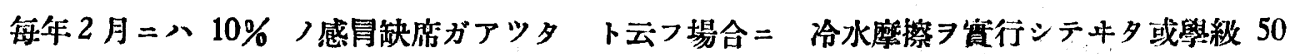
名ノ中 3 人郎チ $6 \%$ シカ感冒缺席ガナカツタトスレバ

從來ノ通リナラパ

今间八

\section{出. 管}

45

47

\section{缺 第}

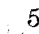

3
トナルべキ所

トナツタ故

$$
\chi^{2}=\frac{(+2)^{2}}{45}+\frac{(-2)^{2}}{5}=\frac{4 \times 50}{225}=0.889
$$

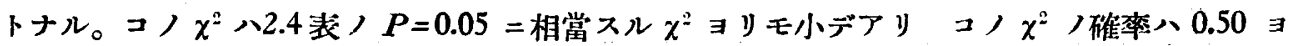

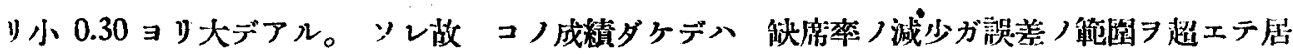
ルトハ云ヘナイ。隨ツテ冷水摩擦ノ效果ガアツタトハ云へナイ。

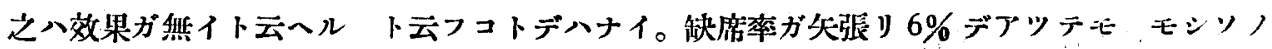

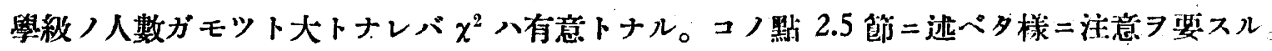

モシ 50 人ノ中ノ1人モ缺帛ガ䍢かツタトスレバドウデアラウカ。

從來通 リ

出席

今间

5

50
缺第

0

$$
\chi^{2}=\frac{5^{2}}{45}+\frac{5^{2}}{5}=\frac{25 \times 50}{225}=5.556
$$

此ノ場合二ハ $\boldsymbol{X}^{2}$ ノ確率入 $0.05>P>0.01$ デアルカラ缺席率ノ減少八確カ 椧水摩擦以外

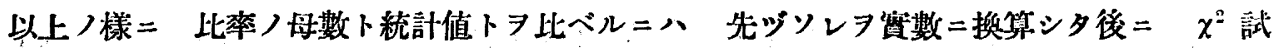
驗 ヨ行へバ良イ。之ヨ換算シナイデ 此率ノママ $\chi^{2}$ 試驗 明ラカナ通り，此率ダケデ算出シタ， $\chi^{2}=$ 資料ノ大キサ $N$ ヨ乘ズレバ良イ。文 2.7 裴习見 
2.7 裴 資料队ノ個能カ゚ $\mathrm{A}$ ト non $\mathrm{A}=$ 分レル時 $\mathrm{A}$ ノ

存在スル此率 $p=$ 就テノ $\chi^{2}$ 算出法

\begin{tabular}{|c|c|c|c|c|c|}
\hline \multicolumn{3}{|c|}{ 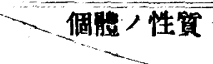 } & A & non A & 訪 \\
\hline 算 & 測 & 值 & $N_{\mathrm{p}}$ & $N(1-\mathrm{p})$ & $N$ \\
\hline 理 & $8 \times]$ & 值 & $N P$ & $N(1-P)$ & $N$ \\
\hline
\end{tabular}

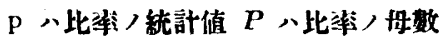

$$
\begin{aligned}
\lambda^{2} & =\frac{(N \mathrm{p}-N P)^{2}}{N P}+\frac{(N-N \mathrm{p}-N+N P)^{2}}{N(1-P)}=\frac{N(\mathrm{p}-P)^{2}}{P(1-P)} \\
& =N \times\left[\frac{(\mathrm{p}-P)^{2}}{P}+\frac{[(1-\mathrm{p})-(1-P)]^{2}}{1-P}\right] \ldots \ldots \ldots \ldots
\end{aligned}
$$

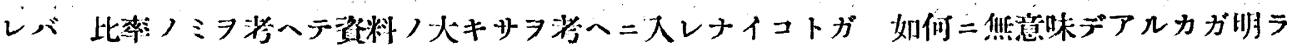

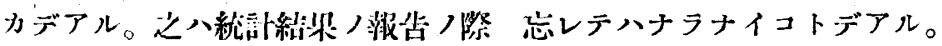

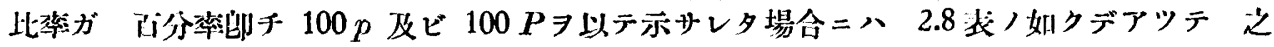

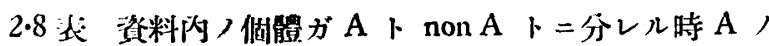

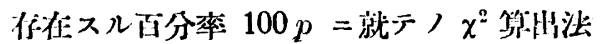

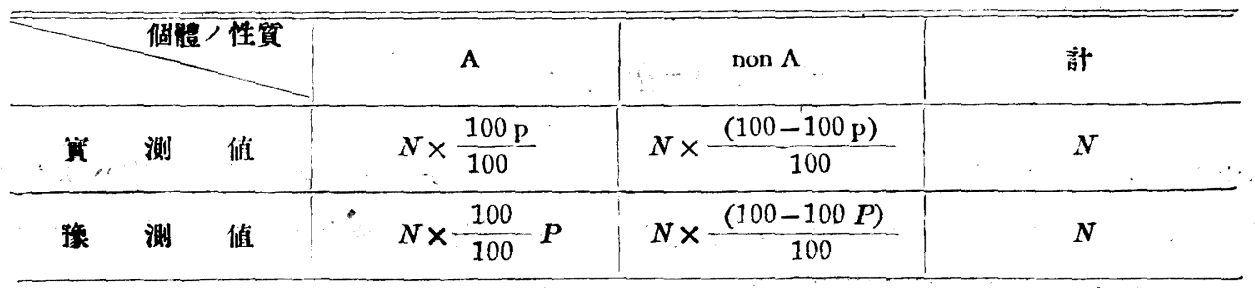

$100 \mathrm{p}$. 百分算, 統計值

$100 \boldsymbol{P}$ ，百分絜，母数

$$
\begin{aligned}
\chi^{2} & =\frac{N=\left(\frac{100 \mathrm{p}-100 P}{100}\right)^{2}}{N \times \frac{100}{100} P}+\frac{N=\left(\frac{100 P-100 \mathrm{p}}{100}\right)^{2}}{N\left(\frac{100-100 P}{100}\right)}=\frac{N(100 \mathrm{p}-100 P)^{2}}{100 P(100-100 P)} \\
& =\frac{N}{100} \times\left[\frac{(100 \mathrm{p}-100 P)^{2}}{100 P}+\frac{[(100-100 \mathrm{p})-(100-100 P)]^{2}}{100-100 P}\right] \ldots \ldots
\end{aligned}
$$

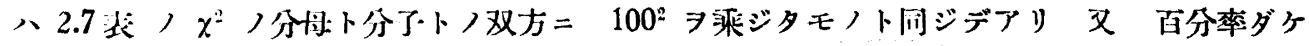

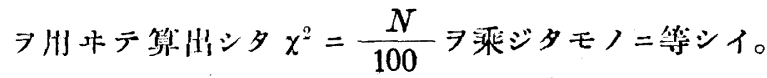

\section{8 ニツノ资料ノ比率ノ比較}

ニツノ資料ガアル時,ソノ此率习比ベルニ八 上述ノ方法ソノマ、デハ不可デアル。何トナ

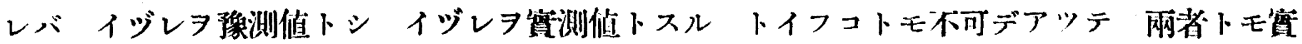

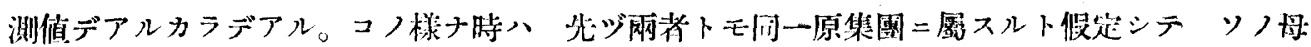




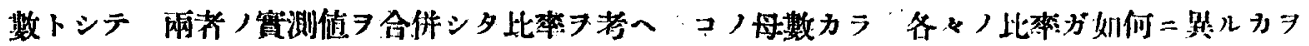
$\chi^{2}$ デ表ハシ 之ノ有意性ヨ檢討スレバョイ。即チ 2.9 裴ノ如クデアル。

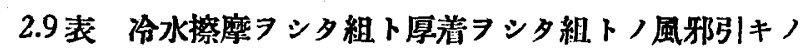

比率ノ比較, $x^{2}$ 試驗（）内八豫湖值

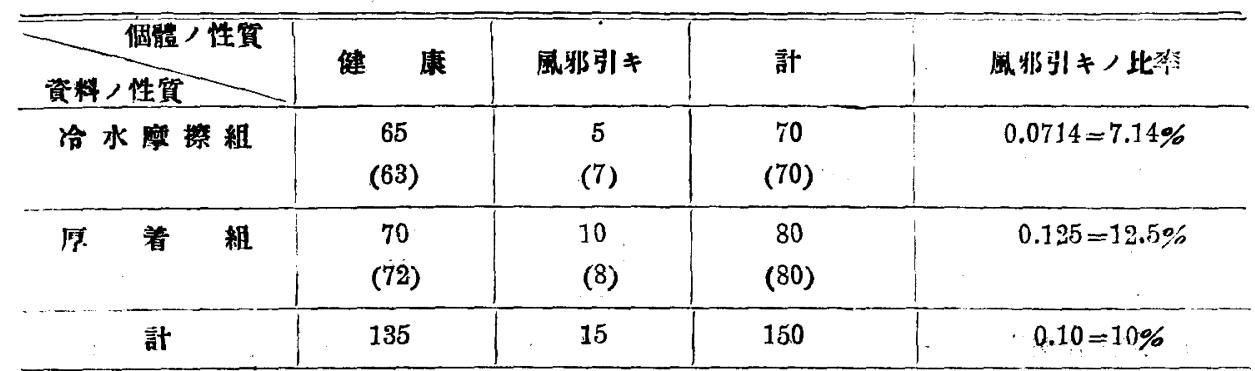

稳測优 7 八算出 : $70 \times \frac{15}{150}=7$

$\begin{array}{lrlll}\prime \prime & 63 & \prime \prime & : & 70-7=63 \\ \prime \prime & 8 & \prime \prime & : & 15-7=8 \\ \prime \prime & 72 & \prime \prime & : & 80-8=79\end{array}$

$\chi^{2}=2^{2}\left(\frac{1}{7}+\frac{1}{63}+\frac{1}{8}+\frac{1}{72}\right)^{\prime}=1.16$

コノ $\chi^{2}$ ノ自由度數入幾何デアルカ。獭測值入 4 倜アルガソノ中 1 倜ノミ自的二定メラレ

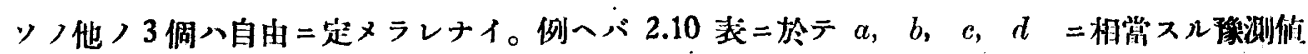
ヨ夫ฬ $a^{\prime}, l^{\prime}, c^{\prime}, d^{\prime}$ トスレバ 假リ $=a^{\prime}$ ヨ自由=定メタトスレバ

$l^{\prime}=(a+b)-a^{\prime}, \quad c^{\prime}=(a+c)-a^{\prime}$

$d^{\prime}=(d+b)-b^{\prime}$ 又八 $=(c+d)-c^{\prime}$

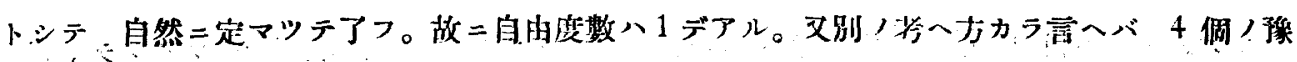

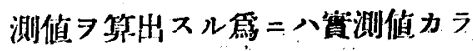

$(a+b),(a+c), N$ 刃八

$(a+b),(a+c),(b+d)$ 又八

$(a+b),(a+c),(c+d)$ 又八

$(a+b),(a+c),(b+d),(c+d), N$ ノ中ノィッ゙レカノ 3 倜

八值ガ利用サレナケレバナラナイ。ソレ故，

自由度數 $=4-3=1$ デアル。

以上ノ方法ニヨリ算出サレタ $\chi^{9}$ 八自由度数 $=1$ デアルカラ ソノ有意性ノ檢查二八第 2.4 表つ數值ヨ用中得ルコトガ分ルデアラウ。以上ノ關係タ一般的ニ示セバ 2.10 表つ如クナル。

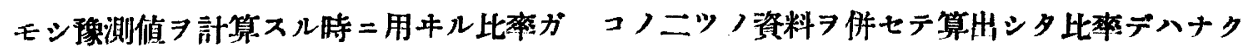




\subsection{0 表 三ツノ資料ノ比率ノ比較・ $\chi^{2}$ 試驗,}

一般形式, 〔つ內 入豫測值

\begin{tabular}{|c|c|c|c|c|}
\hline 资類，種類 & $A$ & non $A$ & 計 & 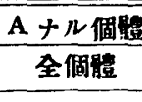 \\
\hline $\begin{array}{l}\mathrm{I} \\
\because \\
\end{array}$ & $\left.a^{\prime}=N_{1} \times \frac{(a+c)}{N}\right]$ & $\begin{array}{c}b \\
{\left[b^{\prime}=N_{1}-a^{\prime}\right]}\end{array}$ & $\begin{array}{r}a+b \\
=N_{1}\end{array}$ & $\begin{array}{l}a /(a+b) \\
=a / N_{1}\end{array}$ \\
\hline II & $\begin{array}{c}c \\
{\left[c^{\prime}=a+c-a^{\prime}\right]}\end{array}$ & $\begin{array}{c}d \\
{\left[d^{\prime}=N_{2}-c^{\prime}\right]}\end{array}$ & $\begin{array}{l}c+d \\
=N_{2}\end{array}$ & $\begin{aligned} & c /(c+d) \\
= & c / N_{2}\end{aligned}$ \\
\hline 計 & $a+c$ & $b+d$ & $\begin{array}{l}a+b+c+d \\
=N_{1}+N_{2}=N\end{array}$ & $\frac{a+c}{N}$ \\
\hline
\end{tabular}

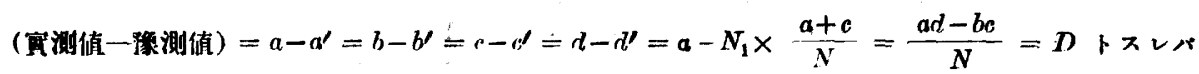

$$
\begin{aligned}
& \chi^{2}=D^{2}\left(\frac{1}{a^{\prime}}+\frac{1}{b_{\mathrm{t}}}+\frac{1}{c^{\prime}}+\frac{1}{d^{\prime}}\right)=\frac{(a d-b c)^{2}}{N^{2}}\left(\frac{1}{a^{\prime}}+\frac{1}{b^{\prime}}+\frac{1}{c^{\prime}}+\frac{1}{d^{\prime}}\right) \\
& \text { メ }=\frac{(a d-b c)^{2} N}{(a+b)(c+d)(a+c)(b+d)} \quad \cdots \cdots \cdots \cdots \cdots(2.3)
\end{aligned}
$$

何等カノ經驗又八理諭カラ既=制ツデ居ルモノデアレバ 像測值ノ算出二必要ナ實測值八 $(a+b)$ ト $(c+d)$, ニツノミデアル。

ソ上故

自由度数 $=4-2=2$

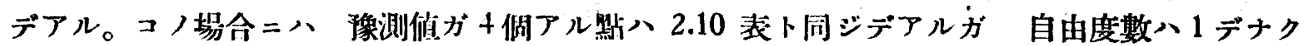
テ 2 デアル。コノ點世上往ハニシテ混同セラレルカラ注意ヨ要スル。之ハ本邦刊行ノ統計書 二自由度数ナル概念ガ欠ケテ居ルカラデアル。

サテ此ノ樣二自由度數 $=2$ ナル時八 2.4 表ノ $レ=1$ ナル 行ノ值八利用出來ナイノデ, 自由 度數 2 以上ナル時ノ $\lambda^{2}$ ノ考察ガ必要ニナツテ來ル。コノ事八次章二述べョウ。 